\title{
Microbiological Profile of Chronic Suppurative Otitis Media
}

\author{
Harish Ghogare, Vijay Vitore, Sunil Hatkar*, M.H. Bhalchandra, A.S. Wyawhare and \\ V.P. Bansal
}

Department of Microbiology, MGM Medical College, Aurangabad, India

*Corresponding author

\section{Keywords \\ CSOM, \\ Polymicrobial infection}

Article Info

Accepted:

10 September 2018 Available Online: 10 October 2018

\section{A B S T R A C T}

Chronic suppurative otitis media (CSOM) is a persistent, insidious and potentially dangerous disease because of its various fatal complications. It is still a significant health problem in developing countries. It is the common cause of conductive deafness. Change in the bacteriological scenario with indiscriminate use of antimicrobial agents has been associated with the emergence of multiple drug resistant strains. Information regarding the common pathogens and their antibiotic sensitivities is essential for the proper choice of antibiotics. Hence the present study is undertaken to know the aerobic bacteriological flora of CSOM and their antibiogram. One hundred and nine clinically diagnosed cases of CSOM of all age groups and both the sexes attending ENT OPD and admitted in ENT wards were studied. Ear swab was taken from each patient, further subjected to Gram staining and culture onto blood agar, MacConkey's agar and Chocolate agar. The bacterial isolates were identified by standard biochemical reactions. Antibiotic susceptibility testing was done by Kirby-Bauer disc diffusion method. A random selection of 109 CSOM cases was studied, of which 71 were males and 38 were females. Majority of the patients were in the age group of 11 to 20 years. Predominance of Pseudomonas aeruginosa $(53.91 \%)$ followed by Staphylococcus aureus (28.69\%), Proteus mirabilis (6.09\%), Klebsiella pneumoniae (5.23\%), Citrobacter freundii (4.35\%) and Escherichia coli (1.73\%). Antibiotics like Imipenem, Piperacillin-tazobactum, Amikacin, ciprofloxacin and Levofloxacin were found to be more effective against all Gram positive and Gram negative isolates. Pseudomonas aeruginosa was the predominant organism followed by Staphylococcus aureus, Proteus mirabilis, Klebsiella pneumoniae, Citrobacter freundii and E. coli. The most effective drugs were Imipenem, Piperacillin-tazobactum, Amikacin, ciprofloxacin and Levofloxacin.

\section{Introduction}

Otitis media is an inflammation of the middle ear \& mastoid process, which could be acute purulent otitis media, otitis media with effusion and chronic suppurative otitis media (CSOM) (Berman, 1997). CSOM is a condition of non-healing perforation of the tympanic membrane associated with chronic inflammatory changes of the Mucoperiosteum of the middle ear cleft resulting in mucoid or mucopurulent otorrhea of more than three months duration (Nwabuisi and Ologe, 2002; Sharma et al., 2004). CSOM is a major problem in developing countries like India. It is more common in children 
belonging to lower socioeconomic group (Lasisi et al., 2007). It is single most important cause of hearing impairment in our country (Srivastava et al., 2010).

The study of microorganisms associated CSOM and their antibiotic sensitivity pattern is most important for clinician to plan general outline of treatment of chronically discharging ear (Greval and Ram, 1996). The most common microorganisms found in CSOM are Pseudomonas aeruginosa, Staphylococcus aureus, Proteus mirabilis, Klebsiella species, Escherichia coli, Aspergillus spp, and Candida Spp, but these organisms vary in various geographical areas (Anwar-us-Salam and Abdulla, 1997).

Early and effective treatment based on the knowledge of causing microorganisms and their sensitivity results in good clinical recovery and prevents damage and complications caused by CSOM (Taneja, 1999). Antimicrobial therapy used to eradicate the bacterial agents causing otitis media but most of the microorganisms are acquiring antibiotic resistance. In developing countries, this problem is rapidly increasing due to misuse of antibiotics. The important factors associated with occurrence CSOM found to be a poor hospital hygiene, overcrowding, lack of resources for infection control and lack of personnel trained in controlling infections in hospital (Hart and Kariuki, 1998).

Pseudomonas aeruginosa is the most predominant organism among the cases of CSOM reported by several workers in India and abroad with an incidence ranging from $21 \%$ to $52.14 \%$ (Gulati et al., 1969; Ayyagari et al., 1981; Rao and Bhaskaran, 1984). Pseudomonas aeruginosa possesses an intrinsic resistance to many antibiotics and has an ability to develop resistance through mutations in different loci or through the horizontal acquisition of resistant genes, which carried on plasmids, transposons or integrons (Bannerman et al., 2007).

The changing flora of CSOM and emergence of strains resistant to the commonly employed antibiotics stimulated this study. The present work deals with the bacteriological study of CSOM to identify and categorize various organisms isolated and to evaluate their sensitivity pattern (Agrawal et al., 2013).

\section{Materials and Methods}

The present study carried out after the clearance from the ethical committee in the department of Microbiology at Tertiary care hospital.

Total 109 patients presenting with ear discharge for more than 3 months of age group varying from 1-70 years and both sexes were included in the study. Medical history were noted including ear discharge, its duration, hearing status, previous history of upper respiratory tract infection (URTI), ear surgery and ear trauma, presence of nasal allergy, chronic tonsilitis, tuberculosis etc.

Ear discharge collected under aseptic precaution in clinically diagnosed cases of CSOM with sterile cotton wool swabs. Excess discharge was mopped out from external auditory canal and it was cleaned with $70 \%$ alcohol first and was allowed to act for 30-40 seconds to achieve sterile area (Vartiainen and Vartiainen, 1996; Gopichand et al., 2015).

The specimens were cultured on blood agar, MacConkey's agar and chocolate agar for aerobic bacteria and incubated at $37^{\circ} \mathrm{C}$ overnight (18-24 hours). The reading of the plate, colony identification, Gram Stain, biochemical test was done as per standard microbiological method (Forbes et al., 2002). A plate showing no growth after 48 hours was considered as negative. The antimicrobial 
susceptibility was performed on Mueller Hinton Agar (MHA) by Kirby Bauer disc diffusion method as per CLSI guidelines (Biemer, 1973; Jorgensen et al., 2007).

\section{Inclusion criteria}

The patients with active aural discharge for more than 3 months belonging to different age, sex, religion and different classes were included in the study. The samples were further subjected to aerobic culture and Gram stain.

\section{Exclusion criteria}

Patients with history of using antibiotic either systemic or local in the form of ear drops for last 7 days were excluded in the study.

\section{Results and Discussion}

A total of 109 patients having CSOM were studied, different organisms are isolated and their antibiogram was done. The results were correlated with demographic data of the individuals.

Chronic suppurative otitis media (CSOM) is a condition of the middle ear characterized by persistent or recurrent discharge through a chronic perforation of the tympanic membrane. Due to the perforated tympanic membrane, bacteria can gain entry into the middle ear via the external ear canal. Infection of the middle ear mucosa subsequently results in ear discharge. Untreated cases of CSOM can result in broad range of complications that leads to spread of bacteria to structures adjacent to the ear or to local damage in the middle ear and such complications are ranges from persistent otorrhea, mastoiditis, labyrinthitis, facial nerve palsy and intracranial abscesses or thromboses. While the incidence of such complications is low, they need to be borne in mind when faced by a patient with active CSOM. Hence, early and effectively treatment required to avoid such complications (Loy et al., 2002).

In the present study maximum number of patients $47(42 \%)$ were in the age group of 1120 years. Studies conducted by (Poorey, 2002), (Vijaya and Nagarathnamma, 1998) and (Urmil Mohan and Jindal, 1998) have reported maximum number of patients belonging to the second decade. The higher incidence of otitis media in first two decades may be due to abundance of lymphoid tissue in children that may obstruct the eustachian tube and increased risk of respiratory infection in children may result in CSOM. The infection of CSOM was more common in males 71 (65\%) than the females 38 (35\%). The male predominance may be because of their more exposed way of life (Varshney and Gupta, 1999). The CSOM cases were more common in rural area $60(55 \%)$ as compared to urban area $49(45 \%)$ which is in accordance with (Gulati, 1997) and (Urmil Mohan and Jindal, 1998). Incidence of CSOM is high in rural areas because of lack of education, awareness and availability of trained specialists. The CSOM cases were more prevalent during winter season 59(54\%) and during early spring $30(28 \%)$ which is correlated with Kathleen A. Daly (1991) and Charles D Bluestone (2004). Nwokoye et al., (2012) have reported increased incidence of CSOM in rainy season (May-Oct). Increased incidences in winter season are mainly attributed to repeated upper respiratory tract infection (viral, bacterial) (Paparella et al., 1991).

The factor associated with socio-economic status were also evaluated and it was observed that CSOM was more among lower socioeconomic class $(59 \%)$ followed by middle class $(30 \%)$ and $11 \%$ in upper class individuals. This finding correlates with studies of Gulati (1997), Urmil Mohan and Jindal (1998) (Table 1-5). 
Table.1 Demographic data of CSOM patients $(n=109)$

\begin{tabular}{|l|l|l|l|}
\hline Categories & & Frequency & Percentage \\
\hline Age group in years & $1-10$ & 16 & $15 \%$ \\
\hline $11-20$ & $41-30$ & 20 & $42 \%$ \\
\hline $31-40$ & 15 & $18 \%$ \\
\hline $41-50$ & 03 & $14 \%$ \\
\hline $51-60$ & 04 & $03 \%$ \\
\hline \multirow{5}{*}{ Gender } & $61-70$ & 04 & $04 \%$ \\
\hline Total & Male & $\mathbf{1 0 9}$ & $04 \%$ \\
\hline Area & Female & 71 & $\mathbf{1 0 0 \%}$ \\
\hline Total & 38 & $65 \%$ \\
\hline Urban & $\mathbf{1 0 9}$ & $35 \%$ \\
\hline Season & Rural & 49 & $45 \%$ \\
\hline Total & 60 & $55 \%$ \\
\hline March-June & $\mathbf{1 0 9}$ & $\mathbf{1 0 0 \%}$ \\
\hline July - October & 20 & $18 \%$ \\
\hline November- February & 30 & $28 \%$ \\
\hline Total & 59 & $54 \%$ \\
\hline & Lower & $\mathbf{1 0 9}$ & $\mathbf{1 0 0 \%}$ \\
\hline & Middle & 64 & $59 \%$ \\
\hline Upper & 33 & $30 \%$ \\
\hline & Total & 12 & $11 \%$ \\
\hline & & $\mathbf{1 0 9}$ & $\mathbf{1 0 0 \%}$ \\
\hline
\end{tabular}

Table.2 Incidence of pure and mixed culture

\begin{tabular}{|l|l|l|}
\hline Organisms & Frequency & Percentage \\
\hline Monomicrobial & 88 & $81 \%$ \\
\hline Polymicrobial & 21 & $19 \%$ \\
\hline Total & 109 & $100 \%$ \\
\hline
\end{tabular}

Table.3 Incidence of polymicrobial bacterial isolates

\begin{tabular}{|l|l|l|l|}
\hline Sr. No & Organisms & Frequency & Percentage \\
\hline $\mathbf{1}$ & Staph. aureus \& P. aeruginosa & 11 & $52 \%$ \\
\hline 2 & Proteus mirabilis \& P. aeruginosa & 4 & $18 \%$ \\
\hline 3 & Staph.aureus \& Citrobacter & 1 & $05 \%$ \\
\hline 4 & E. coli \& Staph.aureus & 1 & $05 \%$ \\
\hline 5 & P. aeruginosa \& E. coli & 1 & $05 \%$ \\
\hline 6 & Proteus Mirabilis \& Staph. aureus & 1 & $05 \%$ \\
\hline 7 & P. aeruginosa \& K. pneumoniae & 1 & $05 \%$ \\
\hline $\mathbf{9}$ & Citrobacter \& K. pneumoniae & 1 & $05 \%$ \\
\hline & Total & 21 & $100 \%$ \\
\hline
\end{tabular}


Table.4 Antibiotic susceptibility pattern of gram-negative organisms

\begin{tabular}{|l|l|l|l|l|l|}
\hline Antibiotics & $\begin{array}{l}\text { Pseudomonas } \\
\text { aeruginosa } \\
(62)\end{array}$ & $\begin{array}{l}\text { Proteus } \\
\text { mirabilis } \\
(07)\end{array}$ & $\begin{array}{l}\text { Klebsiella } \\
\text { pneumoniae } \\
(06)\end{array}$ & $\begin{array}{l}\text { Citrobacte } \\
\text { freundii (05) }\end{array}$ & $\begin{array}{l}\text { Escherichia } \\
\text { coli (02) }\end{array}$ \\
\hline Ciprofloxacin & $33(53 \%)$ & - & - & - & - \\
\hline Co-trimoxazole & - & $1(14 \%)$ & $05(83 \%)$ & $0(00 \%)$ & $1(50 \%)$ \\
\hline Amikacin & $39(63 \%)$ & $6(86 \%)$ & $05(83 \%)$ & $3(50 \%)$ & $2(100 \%)$ \\
\hline Levofloxacin & $28(45 \%)$ & $5(71 \%)$ & $02(33 \%)$ & $2(40 \%)$ & $2(100 \%)$ \\
\hline Amoxy-clav & - & $1(14 \%)$ & $02(33 \%)$ & $0(00 \%)$ & $0(00 \%)$ \\
\hline Ofloxacin & - & $5(71 \%)$ & $4(67 \%)$ & $2(40 \%)$ & $2(100 \%)$ \\
\hline Piperacillin & $27(44 \%)$ & - & - & - & - \\
\hline Piperacillin- & $49(79 \%)$ & $6(86 \%)$ & $1(17 \%)$ & $1(20 \%)$ & $0(00 \%)$ \\
\hline Tazobactum & $13(21 \%)$ & - & - & - & - \\
\hline Ceftaridim & - & $01(14 \%)$ & $1(17 \%)$ & $2(40 \%)$ & $2(100 \%)$ \\
\hline Cefixim & $62(100 \%)$ & $5(71 \%)$ & $3(50 \%)$ & $2(40 \% 0$ & $1(50 \%)$ \\
\hline Imipenem & - & $0(00 \%)$ & $3(50 \%)$ & $0(00 \%)$ & $0(00 \%)$ \\
\hline Cefuroxime & - & $2(29 \%)$ & $4(67 \%)$ & $1(20 \%)$ & $0(00 \%)$ \\
\hline Cefeperozone & - & $1(14 \%)$ & $3(50 \% 0$ & $0(00 \%)$ & $0(00 \%)$ \\
\hline Ceftriaxone & - & - & - & - & - \\
\hline Cefepime & $12(19 \%)$ & & & \\
\hline
\end{tabular}

Table.5 Antibiotic sensitivity pattern of Gram positive organisms

\begin{tabular}{|l|l|l|}
\hline & \multicolumn{2}{|l|}{ Staphylococcus aureus (33) } \\
\hline Antibiotics & Frequency & Percentage \\
\hline Penicillin & 11 & 33 \\
\hline Cefoxitin & 09 & 27 \\
\hline Erythromycin & 12 & 36 \\
\hline Clindamycin & 17 & 52 \\
\hline Ciprofloxacin & 17 & 52 \\
\hline Co-trimoxazole & 15 & 45 \\
\hline Linezolid & 17 & 52 \\
\hline Amikacin & 19 & 58 \\
\hline Levofloxacine & 18 & 55 \\
\hline Doxycycline & 04 & 12 \\
\hline
\end{tabular}

The criteria for socio-economic status was as follows- lower ( $<3000 /$ month), middle (300014000/month) and upper class (>14000/month) (Paparella et al., 1991). It is presumed that multiple factors such as poor sanitation, unhygienic living conditions, overcrowding, malnutrition, illiteracy and lack of health consciousness in low socioeconomic status may contribute to the increased development of otitis media (Hivemath et al., 2001).

The polymicrobial infection was 21(19\%), which is in accordance with (Poorey, 2002). 
However, (Rao and Reddy, 1994) found equal incidence of mixed and pure culture. Use of topical and systemic broad-spectrum antibiotics in the period before consultation was probably responsible for the lower incidence of mixed infection (Koppad). Although in the present study patients not taken antibiotics were amongst the exclusion criteria, but as CSOM being chronic disease patients must have been taken topical or systemic antibiotics by local general practitioners and this is probably responsible for lower incidence of mixed infection (Koppad).

In the present study $P$. aeruginosa was the predominant organism $62(53.91 \%)$ followed by Staphylococcus aureus 33 (28.69\%), Proteus mirabilis 7 (6.09\%), Klebsiella pneumoniae 06 (5.23\%), Citrobacter freundii 5(4.35\%) and Escherichia coli 2(1.73\%). The findings are in accordance with (Shazia parveen and Rao, 2012).

The next predominant organism in the present study was Staphylococcus aureus 33 $(28.69 \%)$. This is in accordance with the finding reported by (Hiremath et al., 2001), (Loy et al., 2002). The frequency of Staphylococcus aureus in the middle ear infections can be attributed to their ubiquitous nature and high carriage of resistant strains in the external auditory canal and upper respiratory tract (Chole and Sudhoff, 1998).

The next most common organism isolated was Proteus mirabilis $7(6.09 \%)$ that correlates with the findings of (Gul et al., 2006) followed by Klebsiella pneumoniae 6 (5.23\%), Citrobacter freundii 5 (4.35\%), and Escherichia coli 2 (1.73\%).

The occurrence of $P$. aeruginosa as the prime offender can be attributed to various factors like minimal nutritional requirement and its armamentarium of antibacterial products, pyocyanin and bacteriocin (Mansoor et al., 2009). The Vartiainen and Vartianen postulated that Pseudomonas has the ability to carve out a niche for itself in local infection through the necrotizing activities of its extracellular enzymes. The physical characteristics of the niche, a damaged epithelium, interrupted circulation and devitalized tissue protects the organism from normal host defense mechanisms and antibiotic agents (Vartiainen and Vartiainen, 1996).

All the isolates were further subjected Antibiotic sensitivity testing, gram negative organisms were $89 \%$ sensitive to Imipenem, followed by Piperacillin-Tazobactum (70\%), Amikacin (67\%), Ciprofloxacin (54\%). (Mansoor et al., 2009) reported similar sensitivity pattern. The $P$. aeruginosa isolates were $100 \%$ sensitive to Imipenem which is in accordance with the studies of (Gul et al., 2006). Among gram-positive organism, Staphylococcus aureus $27 \%$ were resistant to cefoxitin indicating MRSA strains.

When the results of various workers compared, one fact became obvious that the bacteriology and antibiotic sensitivity pattern of CSOM has been changing from time to time. Sensitivity patterns and drug resistance vary according to the region and may give different picture as the time passes on. A carefully selected local and/or systemic antibiotic guided by culture and sensitivity is an effective treatment modality. This will prevent development of drug resistance and administration of unwanted antibiotics.

\section{References}

Agrawal A, Kumar D, Goyal A, Goyal S, Singh N, Khandelwal G. Microbiological profile and their antimicrobial sensitivity pattern in patients of otitis media with ear 
discharge. Indian journal of otology. 2013 Jan 1; 19(1): 5.

Anwar-us-Salam AS, and Abdulla EM. Suppurative otitis in Karachi: An audit of 510 cases. Pak J Otolaryn. 1997; 13:66-9.

Ayyagari A, Pancholi VK, Pandhi SC, Goswami A, Agarwal KC, Mehra YN. Anaerobic bacteria in chronic suppurative otitis media. Indian Journal of Medical Research. 1981; 73:860-4.

Bannerman TL, Peacock SJ, Murray PR, Baron EJ, Jorgensen JH, Landry ML. 2007. Staphylococcus, Micrococcus, and other catalase positive cocci. Manual of clinical microbiology.

Berman S. Classification and criteria of otitis media. Clinical microbiology and infection: the official publication of the European Society of Clinical Microbiology and Infectious Diseases. 1997 Jun; 3:S1-4.

Biemer JJ. Antimicrobial susceptibility testing by the Kirby-Bauer disc diffusion method. Annals of Clinical \& Laboratory Science. 1973 Mar 1; 3(2): 135-40.

Bluestone CD. Otitis media with effusion. Advanced Therapy of Otitis Media. 2004:194.

Chole RA, and Sudhoff HH. Chronic otitis media, mastoiditis, and petrositis. Cumming's otolaryngology head and neck surgery. 1998; 4:2997-3002.

Daly KA. Epidemiology of otitis media. Otolaryngologic Clinics of North America. 1991 Aug; 24(4):775-86.

Forbes BA, Sahm DF, Weissfeld AS. Diagnostic microbiology. Bailey \& Scott1s Diagnostic Microbiology. 2002; 11(1):11-4.

Gopichand WR, Madhusudan BV, Tukaram KV. Bacteriological Profile of Chronic Suppurative Otitis Media. Int. J. Curr. Microbiol. App. Sci. 2015; 4(6):41-7.
Greval RS, and Ram S. Bacteriological patterns of chronic suppurative otitis media in Ludhiana. Indian journal of medical sciences. 1996 Jun; 50(6):1925.

Gül HC, Kurnaz A, Turhan V, Oncül O, Pahsa A. Microorganisms isolated from middle ear cultures and their antibacterial susceptibility in patients with chronic suppurative otitis media. Kulak burun bogaz ihtisas dergisi: $\mathrm{KBB}=$ Journal of ear, nose, and throat. 2006; 16(4):164-8.

Gulati J, Tondon PL, Singh W, Bais AS. Study of bacterial flora in chronic suppurative otitis media. Indian Journal of Otolaryngology and Head \& Neck Surgery. 1969 Dec 1; 21(4):198-202.

Gulati SK. Investigative profile in patients of chronic suppurative otitis media. Indian J Otol. 1997 Jun 3; 3(2):59-62.

Hart CA, and Kariuki S. Antimicrobial resistance in developing countries. BMJ: British Medical Journal. 1998 Sep 5; 317(7159):647.

Hivemath SL, Kanta RC, Yeshwanthrao M. Vasantha Kumar CM. Aerobic bacterial isolates of CSOM and their antibiotic sensitivity pattern. Ind Pract. 2001; 54(7):486-89.

Jorgensen JH, Hindler JF, Reller LB, Weinstein MP. New consensus guidelines from the Clinical and Laboratory Standards Institute for antimicrobial susceptibility testing of infrequently isolated or fastidious bacteria. Clinical infectious diseases. 2007 Jan 15; 44(2):280-6.

Koppad M. Aerobic bacteriological study of chronic suppurative otitis media and their antibiogram (Doctoral dissertation).

Lasisi AO, Sulaiman OA, Afolabi OA. Socioeconomic status and hearing loss in chronic suppurative otitis media in 
Nigeria. Annals of tropical paediatrics. 2007 Dec 1; 27(4):291-6.

Loy AH, Tan AL, Lu PK. Microbiology of chronic suppurative otitis media in Singapore. Singapore medical journal. 2002 Jun; 43(6):296-9.

Mansoor T, Musani MA, Khalid G, Kamal M. Pseudomonas aeruginosa in chronic suppurative otitis media: Sensitivity spectrum against various antibiotics in Karachi. J Ayub Med Coll Abbottabad. 2009 Jun 1; 21(2):120-3.

Mohan U, and Jindal N. Fungal and bacterial flora of chronic suppurative otitis media in Amritsar (Punjab). Indian Journal of Otolaryngology and Head \& Neck Surgery. 1998 Apr 1; 50(2):175-7.

Nwabuisi C, and Ologe FE. Pathogenic agents of chronic suppurative otitis media in Ilorin, Nigeria. East African medical journal. 2002; 79(4):202-5.

Nwokoye NN, Egwari LO. Predisposing and bacteriological features of otitis media. African Journal of Microbiology Research. 2012; 6(3):520-5.

Paparella MM, Kimberley BP, Alleva M. The concept of silent otitis media. Its importance and implications. Otolaryngologic Clinics of North America. 1991 Aug; 24(4):763-74.

Parveen S, and Rao JR. Aerobic bacteriology of Chronic Suppurative Otitis Media (CSOM) in a teaching hospital. $\mathrm{J}$ Microbiol Biotechnol Res. 2012; 2:5869.

Poorey VK. Study of bacterial flora in CSOM and its clinical significance. Indian Journal of Otolaryngology and Head and neck surgery. 2002 Apr 1; 54(2):915.
Rao BN, and Reddy MS. Chronic suppurative otitis media-A prospective study. Indian Journal of Otolaryngology and Head and Neck Surgery. 1994 Apr 1; 46(2):72-7.

Rao R, and Bhaskaran CS. Bacteriology of chronic suppurative otitis media with special reference to anaerobes. Indian journal of pathology \& microbiology. 1984 Oct; 27(4):341-6.

Sharma S, Rehan HS, Goyal A, Jha AK, Upadhyaya S, Mishra SC. Bacteriological profile in chronic suppurative otitis media in Eastern Nepal. Tropical doctor. 2004 Apr; 34(2):102-4.

Srivastava A, Singh RK, Varshney S, Gupta P, Bist SS, Bhagat S, Gupta N. Microbiological evaluation of an active tubotympanic type of chronic suppurative otitis media. Nepalese Journal of ENT Head and Neck Surgery. 2010; 1(2):14-6.

Taneja MK. Contributing factors in otitis media. Indian Journal of Otology. 1999; 5(3):111-4.

Varshney S, and Gupta P. Bacteriological study of chronic suppurative otitis media. Indian Journal of otology. 1999; 5(2):87-91.

Vartiainen E, and Vartiainen J. Effect of aerobic bacteriology on the clinical presentation and treatment results of chronic suppurative otitis media. The Journal of Laryngology \& Otology. 1996 Apr; 110(4):315-8.

Vijaya $D$, and Nagarathnamma $T$. Microbiological study of chronic suppurative otitis media. Indian J Otol. 1998 Dec; 4:172-4.

\section{How to cite this article:}

Harish Ghogare, Vijay Vitore, Sunil Hatkar, M.H. Bhalchandra, A.S. Wyawhare and Bansal, V.P. 2018. Microbiological Profile of Chronic Suppurative Otitis Media. Int.J.Curr.Microbiol.App.Sci. 7(10): 1152-1159. doi: https://doi.org/10.20546/ijcmas.2018.710.128 